\title{
Genetic Structure of Botrytis cinerea Populations from Different Host Plants in California
}

\author{
Zhonghua Ma and Themis J. Michailides, Department of Plant Pathology, University of California-Davis, Kearney \\ Agricultural Center, Parlier 93648
}

\begin{abstract}
Ma, Z., and Michailides, T. J. 2005. Genetic structure of Botrytis cinerea populations from different host plants in California. Plant Dis. 89:1083-1089.

The population structure of Botrytis cinerea was investigated by using transposable elements, DNA fingerprinting generated by microsatellite primed-polymerase chain reaction (MP-PCR), and sensitivity to the hydroxyanilide fungicide, fenhexamid, for 234 isolates collected from fig, grape, kiwifruit, pea, and squash in California. Among 234 isolates tested, 195 had two transposable elements, Boty and Flipper (transposa type), 38 had only the Boty element (Boty type), and one had neither of these elements (vacuma type). Four of these 234 isolates, which belonged to the Boty type, were resistant to fenhexamid. A phenogram generated based on MP-PCR markers showed that the isolates were not clustered based on their source hosts or the presence of transposable elements. Analysis of molecular variance (AMOVA) showed that there were no significant genetic differentiations among isolates collected from grape, kiwifruit, pea, and squash at the Kearney Agricultural Center. A more detailed analysis based on AMOVA partition of the total genetic variance indicated that $96 \%$ of the variation occurred within populations. The parsimony tree length permutation (PTLPT) and index of association $\left(I_{A}\right)$ analyses of MP-PCR data set were consistent with absence of sexual recombination in sampled populations of this pathogen.
\end{abstract}

Botrytis cinerea Pers.:Fr. (teleomorph: Botryotinia fuckeliana (de Bary) Whetzel), the cause of gray mold, is a necrotrophic pathogen causing pre- and postharvest diseases in at least 230 plant species. Gray mold is a serious disease of wine and table grapes, kiwifruit, fig, and stone fruits in California. It also causes blight in pistachio, ornamentals, and vegetables. In California, kiwifruit losses up to $20 \%$ caused by gray mold have been reported (26). Recent studies on French and Chilean populations of $B$. cinerea provided a new finding that this species is composed of two sympatric species, transposa and vacuma $(12,13,27)$, and the transposa isolates did not differ in pathogenicity from the vacuma isolates (21). Transposa has the transposable elements Boty (9) and Flipper (18), whereas these elements are absent in vacuma. Presently, it is unclear whether the two sympatric species are present in $B$. cinerea populations in California. More interestingly, some vacuma isolates are resistant naturally to the hydroxyanilide fungicide, fenhexamid $(1,10,17)$, which is a recently introduced

Corresponding authors:

T. J. Michailides, E-mail: themis@uckac.edu

Z. Ma, E-mail: zhma@uckac.edu

Accepted for publication 27 May 2005.

DOI: 10.1094/PD-89-1083

(C) 2005 The American Phytopathological Society fungicide with a high preventive activity against gray mold on various crops.

Because of the wide range of hosts and tissues that are attacked, and because any strain can infect all plants and organs under laboratory conditions, it had long been thought that $B$. cinerea had no host specificity $(15,19)$. Recent studies on genetic population of $B$. cinerea showed that there were significant genetic differentiations among isolates collected from different host plants in France $(9,13)$ and in Chile (27). Using random amplified polymorphic DNA (RAPD) and polymerase chain reaction-restriction fragment length polymorphism (PCR-RFLP) markers, Muňoz et al. (27) found that isolates sampled from grapes and tomatoes were genetically differentiated. Giraud et al. (12) reported that the prevalence of transposa and vacuma was significantly different in $B$. cinerea populations collected from the different host plants. In light of these recent studies, it appears that $B$. cinerea may have host specialization, which contradicts the traditional view $(15,19)$.

The management of gray mold involves chemical and biological methods, use of organic systems, and protection programs based on disease monitoring and prediction (26). Information on genetic structure of this pathogen population can help us to develop effective strategies for the control of disease $(23,24)$. To our knowledge, population structure of $B$. cinerea in California has not been documented. In this study, we used microsatellite primed (MP)-
PCR to determine the genetic variation in populations of $B$. cinerea because this technique has been shown to be more reliable than use of RAPD markers $(22,32)$, and has been employed as a very powerful tool in population genetic studies $(5,14,20,34)$. The objectives of the present study were to determine (i) whether the two sympatric species of $B$. cinerea, transposa and vacuma, are present in California, (ii) genetic variation in $B$. cinerea populations from different host plants, and (iii) sensitivity of $B$. cinerea isolates to the hydroxyanilide fungicide, fenhexamid.

\section{MATERIALS AND METHODS}

Sample collection. A total of 234 single-spore isolates of $B$. cinerea were collected from different host plants, including 190 from fig, grape, kiwifruit, pea, and squash fields (approximately 100 to $200 \mathrm{~m}$ apart) at the University of California, Kearney Agricultural Center (KAC), Parlier, Fresno County, CA, 22 isolates from a grape orchard in Reedley, $6.5 \mathrm{~km}$ from $\mathrm{KAC}$, and the remaining 22 isolates from a kiwifruit orchard in Kern County, 160 km from KAC. Most of the B. cinerea isolates were collected at $\mathrm{KAC}$, which was chosen because diverse crops were planted in this center, and analysis of large $B$. cinerea samples collected from various hosts at a small area could answer the question on host specialization for the population of this pathogen. Table 1 shows the location, years, organ, and the host plant from which the single-spore isolates were collected.

DNA preparation. Each isolate was grown in a petri dish containing $20 \mathrm{ml}$ of potato dextrose broth (Difco Laboratories, Detroit, MI) at $25^{\circ} \mathrm{C}$ for 4 days. Mycelia were harvested and washed in sterile water, snap frozen in liquid nitrogen, and lyophilized. Fungal genomic DNA was extracted using the FastDNA Kit (Qbiogene Inc., Carlsbad, CA). Final genomic DNA from each isolate was suspended in DNA Elution Solution ultra-pure water (DES). DNA concentration was standardized to $10 \mathrm{ng} / \mu \mathrm{l}$ using the Hoefer DyNA Quant 200 Fluorometer (Hoefer Pharmacia Biotech. Inc., San Francisco, CA). The DNA quality from each isolate was confirmed to be suitable for PCR amplification by generation of a single band with universal primers ITS1 and ITS4 (33).

Detection of transposable elements Boty and Flipper. Boty, a long-terminal 
repeats (LTRs) (9), and Flipper, a mobile Fot1-like transposable element (18), have been identified from $B$. cinerea. The PCR primer pair F300 (5'-GCA CAA AAC CTA CAG AAG A-3') and F1550 (5'-ATT CGT TTC TTG GAC TGT A-3') has been developed to detect the Flipper element successfully (18). This primer pair amplified a 1,250-bp product representing the Flipper element (GenBank accession no. U74294) (18). To detect the element Boty, a pair of primers BotyF4 (5'-CAG CTG CAG TAT ACT GGG GGA-3') and BotyR4 (5'-GGT GCT CAA AGT GTT ACG GGA G-3') was designed based on the DNA sequence of the Boty element (GenBank accession no. X81790). All the primers were synthesized by Invitrogen Life Technologies (Carlsbad, CA).

The PCR reaction was performed in the Eppendorf Mastercycler (Eppendorf AG, Hamburg, Germany) in a $50-\mu \mathrm{l}$ volume containing $50 \mathrm{ng}$ of fungal DNA, $0.2 \mu \mathrm{M}$ of each primer, $0.2 \mathrm{mM}$ of each dNTP (Promega, Madison, WI), $2.0 \mathrm{mM} \mathrm{MgCl}_{2}$, 1× Promega Taq polymerase buffer and 2 U of Promega Taq polymerase. The PCR was performed using the following parameters: an initial preheat for $3 \mathrm{~min}$ at $95^{\circ} \mathrm{C}$, followed by 40 cycles of denaturation at $94^{\circ} \mathrm{C}$ for $40 \mathrm{~s}$, annealing at $60^{\circ} \mathrm{C}$ for the primer pair $\mathrm{F} 300$ and $\mathrm{F} 1550$, or $68^{\circ} \mathrm{C}$ for the primer pair BotyF4 and BotyR4, for $40 \mathrm{~s}$, extension at $72^{\circ} \mathrm{C}$ for $1 \mathrm{~min}$, and terminated with a final extension at $72^{\circ} \mathrm{C}$ for $10 \mathrm{~min}$. PCR products were size verified on $1.5 \%$ agarose gels in Tris-acetate (TAE) buffer. Each isolate was amplified three times with each primer pair.

To verify the approximately 510-bp PCR product amplified by the primer pair BotyF4 and BotyR4 representing the transposable element Boty, the PCR products from two randomly selected isolates KG85 and KG99 were purified using the QIAquick Gel Extraction Kit (QIAGEN Inc., Valencia, CA). The purified fragment from each isolate was ligated into the pGEM-T Easy vector (Promega) and transformed into Escherichia coli (strain JM109) cells. Recombinant plasmids were purified using the QIAprep Spin Miniprep Kit (QIAGEN). The cloned fragments were sequenced by DBS Sequencing Inc. (Division of Biological Sciences, University of California at Davis) using the primer T7. The sequences of the PCR products were compared with the sequences of the Boty element (GenBank accession no. X81790) from B. cinerea using BLAST of NCBI/GenBank (http:// www.ncbi.nlm.nih.gov/BLAST/).

MP-PCR amplifications. For MP-PCR, a total of 16 microsatellite primers were screened for their utility in producing polymorphic bands from $B$. cinerea isolates. PCR amplifications were performed in a 50- $\mu$ l volume containing: $100 \mathrm{ng}$ of template DNA, $1.0 \mu \mathrm{M}$ microsatellite primer, $0.2 \mathrm{mM}$ of each dNTP, $2.5 \mathrm{mM} \mathrm{MgCl} 2,1 \times$ Promega Taq polymerase buffer, and $2 \mathrm{U}$ of Promega Taq polymerase. The PCR was performed using the following parameters: an initial preheat for $3 \mathrm{~min}$ at $95^{\circ} \mathrm{C}$, followed by 40 cycles at $94^{\circ} \mathrm{C}$ for $1 \mathrm{~min}$, $50^{\circ} \mathrm{C}$ for $1 \mathrm{~min}, 72^{\circ} \mathrm{C}$ for $1.5 \mathrm{~min}$, and terminated with a final extension at $72^{\circ} \mathrm{C}$ for $10 \mathrm{~min}$. PCR was performed twice for each isolate. The PCR products were separated on $1.5 \%$ agarose gels in TAE buffer and photographed after staining with ethidium bromide.

Analysis of population structure. Because $B$. cinerea is haploid (8), each MPPCR marker was scored as one putative locus with two alleles, one allele indicating the presence of the amplicon and the other indicating its absence. Each isolate was scored for the presence or absence of each amplicon using Kodak Digital Science ID Image Analysis Software (Eastman Kodak Co., Rochester, NY). Genetic similarities (S) were calculated using Jaccard's similarity coefficient. A phenogram was constructed using the unweighted pair group method with arithmetic average (UPGMA) by the program Sequential, Agglomerative, Hierarchical, and Nested clustering methods (SAHN) of the software package NTSYS-pc 2.1 (Dept. of Ecology and Evolution, State University of New York, NY). Estimation of genetic differentiation $\left(F_{S T}\right)$ between populations by pairwise difference and analysis of molecular variance (AMOVA) among the populations from different hosts at different locations was performed using the software ARLEQUIN (Ver. 2.0, Dept. of Anthropology and Ecology, Genetics and Biometry Laboratory, University of Geneva, Switzerland; http:// lgb.unige.ch/arlequin/). The MP-PCR markers were treated as dominant markers for the haploid fungus, $B$. cinerea.

Analysis of reproductive mode. The parsimony tree length permutation (PTLPT) $(6,28)$ and index of association $\left(I_{A}\right)$ tests were used to analyze the reproductive mode of $B$. cinerea for the sampled populations. Since there were no significant genetic differences among the populations sampled from grape, kiwifruit, pea, and squash at $\mathrm{KAC}$, the isolates collected from these crops were used for the phylogenetic analysis. Sixty-two representative isolates having distinct MP-PCR patterns were selected from 129 isolates to avoid duplication of common genotypes. Linkage disequilibrium was analyzed for the polymorphic MP-PCR markers by using the software Arlequin. After the linkage markers were omitted, 22 nonlinkage MP-PCR markers were used for the analysis. The length of the most parsimonious tree for these representative isolates was obtained using the heuristic search option with 1,000 random addition replicates with tree bisection reconnection (TBR) (PAUP Win 4.0 version, Sinauer Associates, Inc., Publishers, Sunderland, MA). The program Permute of the software was performed to produce the most parsimonious tree from 1,000 randomized data, and a distribution of tree lengths from these 1,000 randomized trees was produced. This distribution can represent the lengths of trees for the isolates sampled from a recombining population. The null hypothesis is that the population sampled undergoes recombination. If the length of the observed tree is significantly shorter than the average length of the trees from recombined data, the hypothesis can be rejected. However, if the observed tree

Table 1. A list of Botrytis cinerea isolates collected from different host plants used in this study

\begin{tabular}{|c|c|c|c|c|c|c|}
\hline \multirow[b]{2}{*}{ Host/organ } & \multirow[b]{2}{*}{ Location } & \multirow[b]{2}{*}{ Date of isolation } & \multirow[b]{2}{*}{ No. of isolates } & \multicolumn{3}{|c|}{ Type of isolate } \\
\hline & & & & Transposa $^{v}$ & Vacuma $^{w}$ & Boty $^{\mathrm{x}}$ \\
\hline Kiwifruit $(\mathrm{KK})^{\mathrm{y} / \text { fruit }}$ & $\mathrm{KAC}^{\mathrm{z}}$ & $11 / 2002$ & 13 & 11 & 0 & 2 \\
\hline Fig (KF)/fruit & $\mathrm{KAC}$ & $11 / 2002$ & 36 & 27 & 1 & 8 \\
\hline Fig (KF03)/fruit & $\mathrm{KAC}$ & $12 / 2003$ & 25 & 18 & 0 & 7 \\
\hline Grape $(K G) /$ fruit & $\mathrm{KAC}$ & $11 / 2002$ & 34 & 33 & 0 & 1 \\
\hline Grape (KG03)/fruit & $\mathrm{KAC}$ & $11 / 2003$ & 24 & 22 & 0 & 2 \\
\hline Pea (KPE)/flower & $\mathrm{KAC}$ & $01 / 2004$ & 20 & 13 & 0 & 7 \\
\hline Squash (KS)/pedicle and fruit & KAC & $11 / 2002$ & 38 & 29 & 0 & 9 \\
\hline Grape (RG)/fruit & Reedley, Fresno, CA & $11 / 2002$ & 22 & 20 & 0 & 2 \\
\hline Kiwifruit $(\mathrm{R}$ or $\mathrm{S}) /$ fruit & Kern, CA & $10 / 2002$ & 22 & 22 & 0 & 0 \\
\hline
\end{tabular}

\footnotetext{
${ }^{\mathrm{v}}$ Isolates having both the transposable elements Boty and Flipper.

${ }^{\mathrm{w}}$ Isolates without the transposable elements Boty and Flipper.

${ }^{\mathrm{x}}$ Isolates containing only the transposable element Boty.

$\mathrm{y}$ Isolate code is indicated in parentheses.

${ }^{\mathrm{z}}$ Kearney Agricultural Center, Parlier, CA.
} 
length is not significantly shorter than the average length of the estimated trees, the sampled isolates should likely come from a population with recombining reproduction (28).

In the $I_{A}$ test for the 62 representative isolates, the program MULTILOCUS (Ver. 1.2, P. M. Agapow and A. Burt, 2000) was used to analyze 22 randomly associated MP-PCR markers. The variance for the observed data was compared with the distribution of variances for 1,000 randomized data sets. This distribution can represent $I_{A}$ for a recombining population. The null hypothesis is that the population sampled undergoes recombination. If the observed $I_{A}$ is significantly higher than the mean of the $I_{A}$ from recombined data, the null hypothesis can be rejected, and the isolates sampled may likely come from a population with clonal reproduction mode. However, if the observed $I_{A}$ is not significantly higher than the mean of the $I_{A}$ from recombined data, the sampled isolates should likely come from a population with recombining reproduction. These two methods were also used to analyze reproductive mode for 61 isolates collected from fig at KAC, 22 isolates from grape at Reedley, and 22 isolates from kiwifruit in Kern County, respectively.

Fungicide sensitivity assays. Fenhexamid (Elevate, 50WDG; Arvesta Co., San Francisco, CA) was dissolved in sterile water, adjusted to the concentration of $10 \mu \mathrm{g}$ a.i./ $\mu \mathrm{l}$, and added to the potato dextrose agar (PDA) (Microtech Scientific Inc., Orange, CA) medium after sterilization to produce the concentrations of 0 , $0.0031,0.0125,0.05,0.2,0.8,3.2$, and $12.8 \mu \mathrm{g}$ a.i. fenhexamid per $\mathrm{ml}$ of medium. A 5-mm mycelial plug was cut from the edge of a 4-day-old colony for each isolate of $B$. cinerea and placed in the center of a PDA dish amended with each of the fungicide concentrations. Two plates for each concentration were used, and the experiment was performed twice. The plates were incubated at $25^{\circ} \mathrm{C}$ for 3 days. For each plate, the colony diameter was measured in two perpendicular directions with the original mycelial plug diameter $(5 \mathrm{~mm})$ subtracted. For each isolate, a linear regression of the percent inhibition related to the control of mycelial growth versus the $\log _{10}$ transformation for each of the seven concentrations of fenhexamid was obtained. The $50 \%$ effective concentration $\left(\mathrm{EC}_{50}\right)$, which is the fungicide concentration that results in 50\% mycelial growth inhibition, was calculated with the regression equation for each isolate.

\section{RESULTS}

Transposable elements. Previous studies $(18,27)$ showed that the primer pair F300 and F1550 was capable of identifying the transposable element, Flipper, and the results from PCR were consistent with those from Southern dot blot. In this study,
PCR with this primer pair consistently amplified the expected 1,250-bp PCR fragment from 195 out of 234 isolates.

The primer pair BotyF4 and BotyR4 consistently generated a 510-bp PCR fragment from 233 out of 234 isolates. The DNA sequence of the 510-bp PCR fragment from the isolates KG85 and KG99 showed 94 and $96 \%$ identity, respectively, to that of the Boty transposable element (GenBank accession no. X81790), which indicated that the 510-bp PCR product was indeed a fragment of the Boty gene, and PCR with the primer pair BotyF4 and BotyR4 was sufficiently robust to identify the transposable element Boty.

Among 234 isolates tested, 195 had both transposable elements, Boty and Flipper, which indicated that transposa isolates were predominant $(83.3 \%)$ in the sampled populations of $B$. cinerea. Only one vacuma isolate, KF91 $(0.43 \%)$, which originated from fig at KAC, was detected (Table 1). The remaining 38 isolates had only the transposable element Boty.

Population structure evaluated by MP-PCR. Ten isolates for screening microsatellite primers were used, and six of 16 primers, $(\mathrm{AAC})_{8},(\mathrm{AAG})_{8},(\mathrm{AG})_{8} \mathrm{C}$, $(\mathrm{CAC})_{5},(\mathrm{GACA})_{4}$, and M13, generated stable MP-PCR band profiles for each isolate in four independent amplifications. The same MP-PCR band profiles were also consistently generated by each of these six primers when DNA templates extracted by different methods and different thermal cyclers were used. These six primers generated a total of 56 amplicons from 234 isolates tested. Among the 56 amplicons, 52 were polymorphic. The number of polymorphic amplicons and total amplicons generated from individual isolates ranged from 18 to 27, and from 22 to 31, respectively. Examples of MP-PCR using the primers $\mathrm{M} 13,(\mathrm{AAC})_{8}$, and (GACA) ${ }_{4}$ are presented in Figure 1. Based on the MPPCR profiles produced by these six primers, 99 haplotypes were found from 234 isolates tested. The Jaccard similarity coefficient values for the 99 haplotypes ranged from 0.24 to 0.97 . A phenogram generated by the UPGMA analysis of the 56 amplicons from the 234 isolates showed that 94 of the 99 haplotypes had similarities more than $80 \%$ (Fig. 2). The representatives of five most common haplotypes (indicated by arrows in Figure 2) had minor differences with similarity more than $87 \%$. UPGMA analysis showed that the isolates were not clustered based on their hosts, locations, or transposable elements (Fig. 2, Table 1).

When the populations from different hosts were compared, the analysis of genetic differentiation revealed that the populations of $B$. cinerea from grape, kiwifruit, squash, and pea at KAC were not significantly different (Table 2). The population
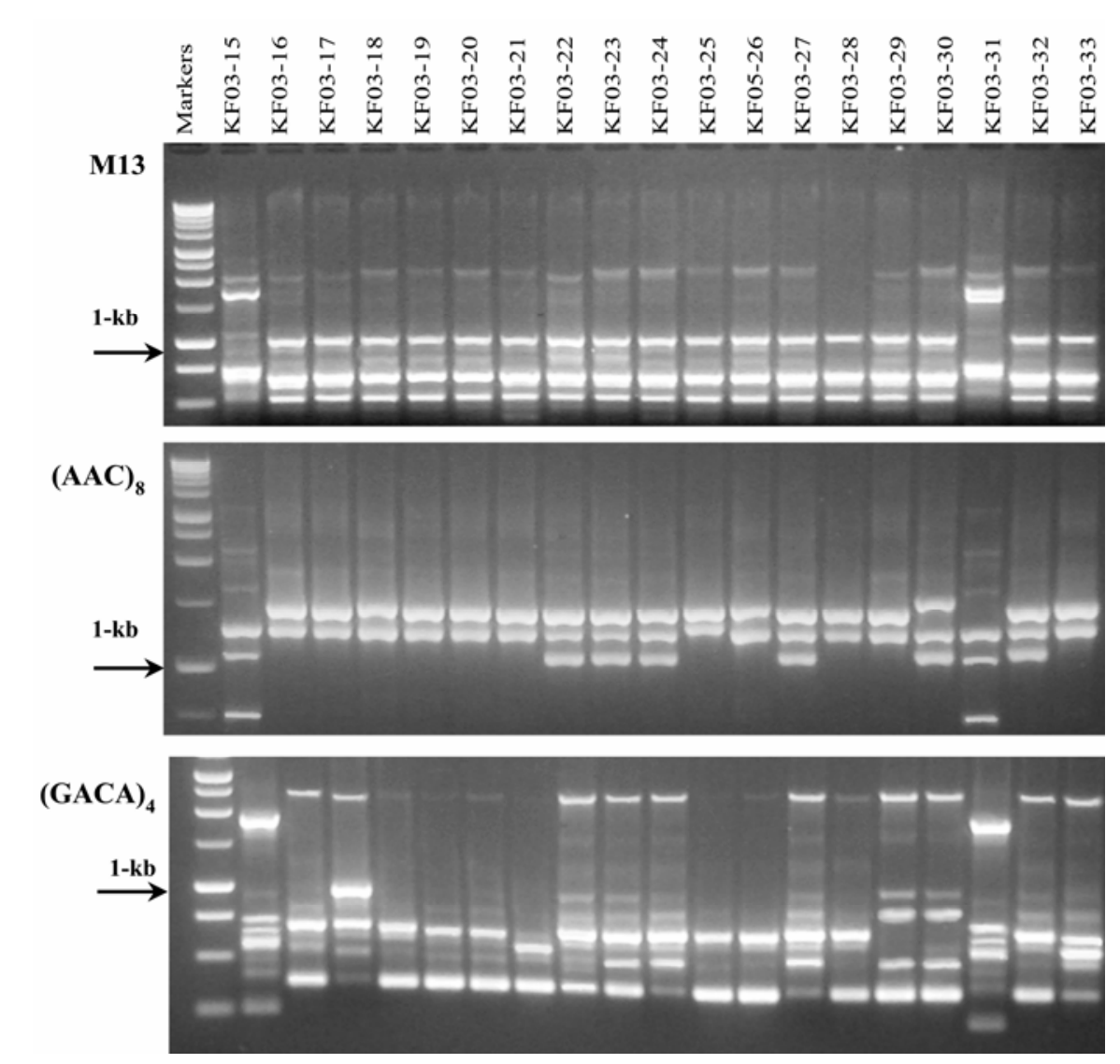

Fig. 1. Examples of electrophoretic separation of polymerase chain reaction (PCR) amplicons of Botrytis cinerea isolates obtained from the microsatellite primers M13, $(\mathrm{AAC})_{8}$, and (GACA) $)_{4}$. 
from fig was genetically different from the population from grape at KAC, but genetic differentiation between these two populations was very low $\left(F_{S T}=0.03\right)$. When the populations from the different locations were compared, we found that the population from a grape orchard in Reedley, 6.5 $\mathrm{km}$ from KAC, was not significantly different from the population from grape at $\operatorname{KAC}\left(F_{S T}=0.006, P=0.225\right)$. The population from a kiwifruit orchard in Kern County, $160 \mathrm{~km}$ from KAC, was significantly different from the population sampled from the same crop at $\mathrm{KAC}\left(F_{S T}=\right.$ $0.08, P=0.027$ ) (Table 2). Additionally, there were no significant genetic differentiations between the isolates collected from grape $\left(F_{S T}=-0.01, P=0.712\right)$ and from fig $\left(F_{S T}=0.008, P=0.541\right)$ in 2002 and 2003.

A more detailed analysis based on AMOVA partition of the total genetic variance indicated that most of the variation (96\%) occurred within the populations. Genetic variation among populations from different host plants at KAC and among locations accounted for only 2 and $2 \%$ of the total genetic variation, respectively (Table 3 ).

Reproductive mode. The most parsimonious tree from the observed MP-PCR data set of 62 representative isolates from kiwifruit, grape, pea, and squash had a length of 104 steps, which was significantly $(P=0.001)$ shorter than the mean length $(118.93 \pm 2.8)$ of 1,000 trees from randomized data sets (Fig. 3). The ob- served $I_{A}$ from MP-PCR data set of these 62 isolates was 10.20 , which was significantly $(P<0.001)$ higher than the mean $I_{A}$ $(0.002)$ of 1,000 randomized data sets (Fig. $4)$. These results revealed that the $B$. cinerea population collected from these crops at KAC was primarily asexual, and frequencies of sexual recombination in the sampled population were too low to randomize associations among loci. Similar results were observed from the isolates collected from fig at $\mathrm{KAC}$, from grape at Reedley, and from kiwifruit in Kern County (data not shown).

Sensitivity of $B$. cinerea to fenhexamid. Among 234 isolates tested, 223 had $\mathrm{EC}_{50}$ values less than $0.13 \mu \mathrm{g} / \mathrm{ml}$ (Fig. $5)$. The $\mathrm{EC}_{50}$ value of the only vacuma

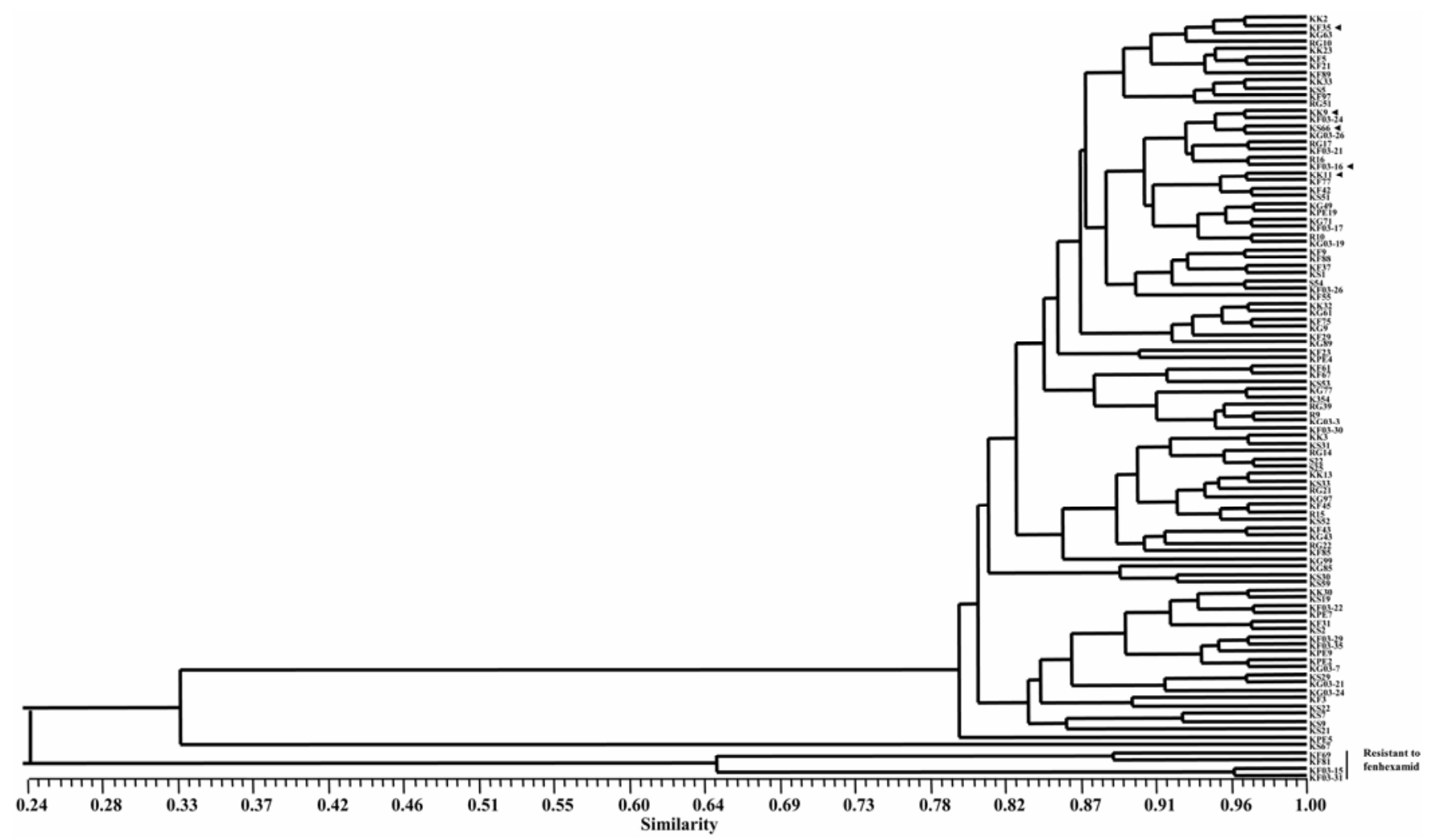

Fig. 2. Unweighted pair group method with arithmetic averages (UPGMA) cluster analysis of microsatellite primed-polymerase chain reaction (MP-PCR) data for Botrytis cinerea isolates representing various genotypes collected from fig, grape, kiwifruit, pea, and squash. The representatives of five most common haplotypes were indicated by arrows.

Table 2. Pairwise $F$ statistics $\left(F_{S T}\right)$ values between populations of Botrytis cinerea collected from different host plants

\begin{tabular}{|c|c|c|c|c|c|c|c|}
\hline Population $^{\mathrm{y}}$ & KAC/kiwifruit & KAC/fig & KAC/grape & KAC/squash & KAC/pea & Reedley/grape & Kern/kiwifruit \\
\hline KAC/kiwifruit & 0.000 & & & & & & \\
\hline KAC/fig & $\begin{array}{c}0.003 \\
(0.324)^{\mathrm{z}}\end{array}$ & 0.000 & & & & & \\
\hline KAC/grape & $\begin{array}{c}-0.032 \\
(0.937)\end{array}$ & $\begin{array}{c}0.032 \\
(0.018)\end{array}$ & 0.000 & & & & \\
\hline KAC/squash & $\begin{array}{l}-0.030 \\
(0.928)\end{array}$ & $\begin{array}{c}0.029 \\
(0.063)\end{array}$ & $\begin{array}{c}0.003 \\
(0.288)\end{array}$ & 0.000 & & & \\
\hline $\mathrm{KAC} / \mathrm{pea}$ & $\begin{array}{c}0.005 \\
(0.451)\end{array}$ & $\begin{array}{c}0.015 \\
(0.243)\end{array}$ & $\begin{array}{l}-0.010 \\
(0.757)\end{array}$ & $\begin{array}{r}-0.007 \\
(0.58)\end{array}$ & 0.000 & & \\
\hline Reedley/grape & $\begin{array}{c}-0.016 \\
(0.523)\end{array}$ & $\begin{array}{c}0.051 \\
(0.045)\end{array}$ & $\begin{array}{c}0.006 \\
(0.225)\end{array}$ & $\begin{array}{c}0.031 \\
(0.09)\end{array}$ & $\begin{array}{c}0.045 \\
(0.000)\end{array}$ & 0.000 & \\
\hline Kern/kiwifruit & $\begin{array}{c}0.080 \\
(0.027)\end{array}$ & $\begin{array}{c}0.078 \\
(0.018)\end{array}$ & $\begin{array}{c}0.021 \\
(0.135)\end{array}$ & $\begin{array}{c}0.091 \\
(0.000)\end{array}$ & $\begin{array}{c}0.033 \\
(0.100)\end{array}$ & $\begin{array}{c}0.073 \\
(0.000)\end{array}$ & 0.000 \\
\hline
\end{tabular}

\footnotetext{
${ }^{y}$ Location/host.

${ }^{\mathrm{z}}$ Numbers in parentheses are $P$ values.
} 
isolate, KF91, was $0.0359 \mu \mathrm{g} / \mathrm{ml}$, suggesting this isolate was sensitive to fenhexamid. Four Boty isolates, KF69, KF81, KF03-15, and KF03-31, all of which were collected from two fig trees at the KAC, had $\mathrm{EC}_{50}$ values greater than $2.8 \mu \mathrm{g} / \mathrm{ml}$ (Fig. 5). The minimum inhibitory concentrations (MICs) of these four isolates were higher than $12.8 \mu \mathrm{g} / \mathrm{ml}$, and all the other 230 isolates had MICs less than 12.8 $\mu \mathrm{g} / \mathrm{ml}$. Thus, these four Boty isolates were considered to be fenhexamid-resistant based on previous studies on the sensitivity of $B$. cinerea to fenhexamid $(16,35)$.

\section{DISCUSSION}

In this study, although both transposa and vacuma were detected, the former was very prevalent $(83.3 \%)$ in the sampled populations of B. cinerea in 2002 to 2004 , and only one vacuma isolate, which originated from fig at KAC, was detected among the 234 isolates tested. Vacuma isolates were not found in samples from grape, kiwifruit, squash, and pea in our samples, but they were found at high frequencies (up to $45 \%$ ) on grape and many other plant species in France (12) and Chile (27). A third type of isolate having only the transposable element Boty was found in our samples. Isolates of this type were also detected recently in Chilean and French samples (27). Surprisingly, although fenhexamid fungicide has never been used at KAC and surrounding areas, four Boty isolates, KF69, KF81, KF03-15, and KF03-31, showed resistance to this fungicide. In previous studies, resistance to fenhexamid has been found from vacuma, transposa, and Flipper isolates, but not from Boty isolates $(1,12)$. In this study, we found that all four fenhexamid-resistant isolates were Boty isolates. These results indicate that there were no clear relationships between sensitivity to fenhexamid and the presence of Boty and/or Flipper elements in B. cinerea.

In this study, MP-PCR fingerprint could not differentiate transposa isolates from vacuma isolates, but did distinguish fenhexamid-sensitive (FenS) from -resistant (FenR) isolates. Although the FenR isolates were isolated from only two fig trees at the $\mathrm{KAC}$, these results are consistent with a recent study by phylogenic analysis of DNA sequence data (11). When analyzing polymorphisms at a vegetableincompatibility locus (Bc-hch) from 117 isolates of $B$. cinerea, Fournier et al. (11) found that the 117 isolates were separated into two groups: all group I isolates were resistant to fenhexamid, and all group II isolates were sensitive to this fungicide. But these two groups did not correspond to transposa and vacuma groups. More importantly, the group I and II isolates could not interbreed (11). Based on results from this previous study and the present study, we propose that naturally FenR and FenS isolates had different ancestors with an independent evolutionary history. However, since only four resistant isolates from two fig trees were detected in this study, more resistant isolates from a large spatial scale need to be examined to determine the degree of genetic differentiation between these FenR and FenS groups.

$B$. cinerea has been found to be highly heterogeneous. Based on the 52 polymor- phic MP-PCR markers, we detected 99 haplotypes from the 234 isolates tested. AMOVA analysis of genetic variation in $B$. cinerea based on MP-PCR markers revealed that the most genetic diversity (96.02\%) was present within populations. These results are consistent with previous studies using RAPD $(2,27,29)$, and RFLP markers $(12,13)$. High levels of haplotypic

Table 3. Hierarchical molecular analysis of variation (AMOVA) within and between populations of Botrytis cinerea based on microsatellite primed-polymerase chain reaction (MP-PCR) markers

\begin{tabular}{lccccc}
\hline $\begin{array}{l}\text { Source of } \\
\text { variation }\end{array}$ & df & $\begin{array}{c}\text { Sum of } \\
\text { squares }\end{array}$ & $\begin{array}{c}\text { Variance } \\
\text { component }\end{array}$ & $\begin{array}{c}\text { Percentage } \\
\text { of variation }\end{array}$ & $\boldsymbol{P}$ value $^{\mathbf{z}}$ \\
\hline Among locations & 2 & 9.23 & 0.04 & 2 & 0.021 \\
$\begin{array}{l}\text { Among populations within } \\
\text { locations }\end{array}$ & 4 & 14.14 & 0.04 & 2 & 0.040 \\
Within populations & 227 & 458.14 & 2.02 & 96 & 0.020 \\
Total & 233 & 481.51 & 2.10 & & \\
\hline
\end{tabular}

${ }^{\mathrm{z}}$ Probability of having larger values than those observed with 1,000 permutations.

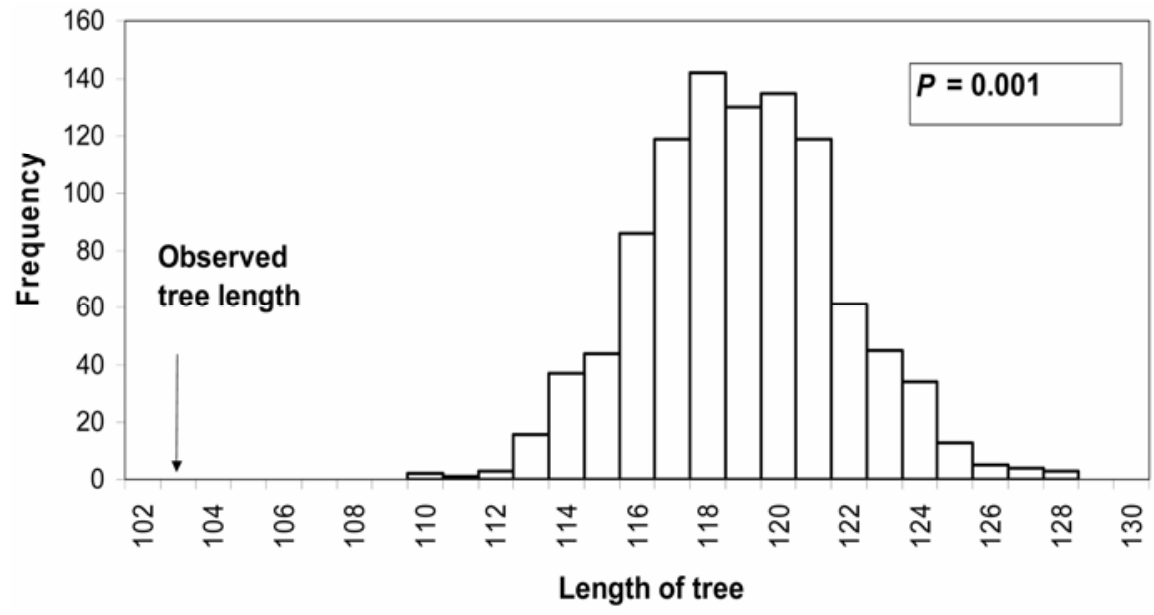

Fig. 3. Observed tree length (indicated by arrow) and tree lengths generated from randomized data sets for Botrytis cinerea isolates collected from kiwifruit, grape, pea, and squash at Kearney Agricultural Center (KAC), Parlier, CA. The 62 distinct isolates representing various DNA haplotypes were selected for phylogenetic analysis of reproductive mode. The distribution was generated from 1,000 randomized trees.

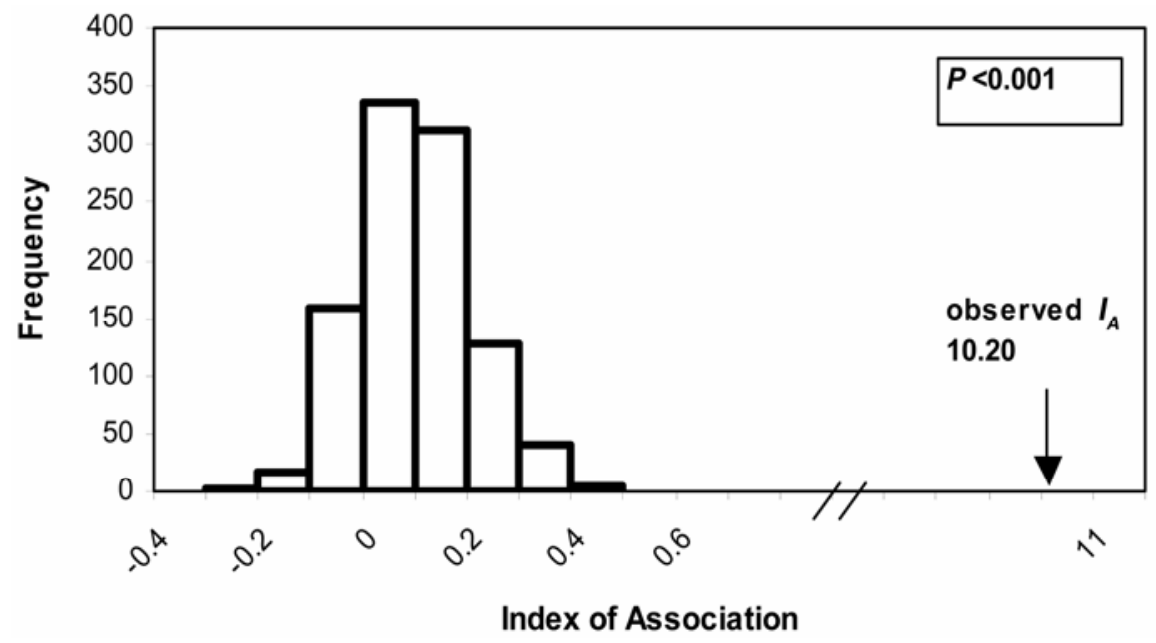

Fig. 4. Observed index of association $\left(I_{A}\right)$ (indicated by arrow) and $I_{A}$ generated from randomized data sets for Botrytis cinerea isolates collected from kiwifruit, grape, pea, and squash at Kearney Agricultural Center (KAC), Parlier, CA. The 62 distinct isolates representing various DNA haplotypes were selected for $I_{A}$ test for analysis of reproductive mode. The distribution was generated from 1,000 independently randomized data sets. 


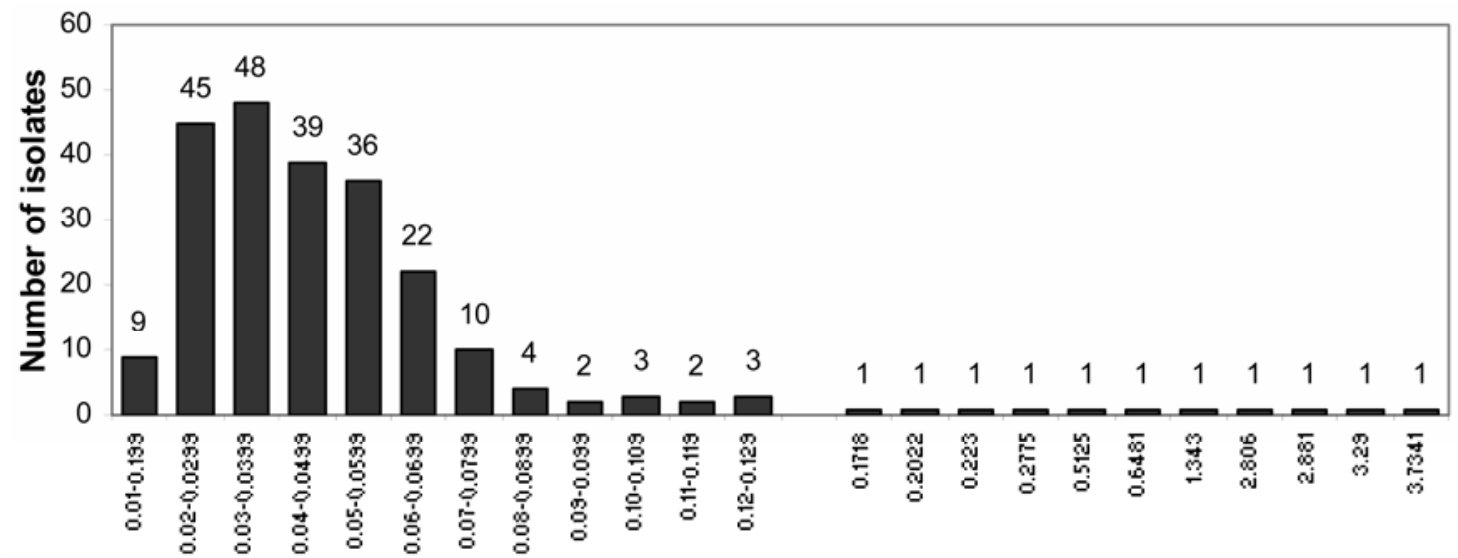

$\mathrm{EC}_{50}$

Fig. 5. Distribution of $50 \%$ effective concentration $\left(\mathrm{EC}_{50}\right)$ of Botrytis cinerea isolates to the hydroxyanilide fungicide, fenhexamid.

diversity in $B$. cinerea populations may mainly result from (i) heterokaryosis and aneuploidy, which are widely accepted as important sources of variation in B. cinerea $(7,19,31)$; (ii) sexual reproduction, which has been suggested for the populations in France (12,13), Spain (30), and Italy (4); (iii) the activity of the transposable elements Boty and Flipper (18,25); and (iv) spontaneous mutation. In this study, both index of association $\left(I_{A}\right)$ test and parsimony tree length permutation (PTLPT) analyses of MP-PCR data indicated that the sampled $B$. cinerea populations were lacking recombination. Additionally, the five most common haplotypes present in the same cluster had only minor differences, which also indicates that the majority of the population came from clonal lineages. Furthermore, despite our intensive search, apothecia of Botryotinia fuckeliana have never been found on the ground in fields in our area. These findings indicated that the high level of haplotypic diversity in the sampled $B$. cinerea populations might result from other mechanisms than sexual reproduction, and frequencies of sexual recombination in sampled populations were too low to be observed if the sexual stage of $B$. cinerea exists in the sampled fields.

Analysis of genetic differentiation showed that there were no significant differences among the populations sampled from grape, kiwifruit, pea, and squash at the same location. Although the population obtained from fig was different from that collected from grape, the low value of pairwise $F_{S T}(0.032)$ indicated that the genetic differentiation between these two populations was small (3). Additionally, UPGMA analysis of MP-PCR markers showed that the isolates were not clustered based on their hosts. These results suggest that host specialization of $B$. cinerea does not occur in the sampled crops (grape, kiwifruit, pea, and squash), although the specificity of this pathogen to some other crops is not excluded.

When the populations at different locations were compared, we did not observe significant genetic differences among the populations from grape at Reedley and KAC. Additionally, most isolates from the Reedley had identical haplotypes with those collected from the KAC. Additionally, a high value $(\mathrm{Nm}=17.67)$ of gene flow, estimated from Nei's population differentiation $\left(G_{S T}\right)$, between KAC and Reedley populations indicates that migratory events of the pathogen were common between these two locations (22). These results indicated that migration of airborne conidia of $B$. cinerea might frequently occur between the KAC and Reedley, since these two locations are separated by only $6.5 \mathrm{~km}$. These findings on migrants of $B$. cinerea among different crops within one location or at different locations have a direct impact on the strategies for management of gray mold, in particular fungicide resistance management and sanitation practices. $B$. cinerea is the classical "high risk pathogen" from the view of resistance management, and newly introduced botryticides face the possibility of resistance development (17). Disease control strategies should be considered at least at the regional level. Once fungicide-resistant genotypes have occurred in one orchard because of one grower not applying the appropriate fungicide program, the resistant genotypes may rapidly spread to other orchards a few kilometers away from the original orchard. In the same way, improper sanitation in one field could increase the inoculum potential in the whole cultivated area. Additionally, since naturally FenR isolates have been detected from the $B$. cinerea sampled, it would be necessary to track the dynamics of such resistant isolates if fenhexamid is used widely for controlling gray mold, although failure of gray mold control in the field with this compound has not been reported.

\section{ACKNOWLEDGMENTS}

We thank Michael A. Yoshimura (Biological Sciences Department, California Polytechnic State University, San Luis Obispo) for testing fungicide sensitivity and David P. Morgan for collecting Botrytis cinerea isolates from kiwifruit. We also thank the anonymous reviewers for their constructive suggestions.

\section{LITERATURE CITED}

1. Albertini, C., Thebaud, G., Fournier, E., and Leroux, P. 2002. Eburicol 14 $\alpha$-demethylase gene (CYP51) polymorphism and speciation in Botrytis cinerea. Mycol. Res. 106:1171-1178.

2. Alfonso, C., Raposo, R., and Melgarego, P. 2000. Genetic diversity in Botrytis cinerea population on vegetable crops in greenhouse in south-eastern Spain. Plant Pathol. 49:243-251.

3. Balloux, F., and Lugon-Moulin, N. 2002. The estimation of population differentiation with microsatellite markers. Mol. Ecol. 11:155-165.

4. Baraldi, E., Bertolini, P., Chierici, E., Trufelli, B., and Luiselli, D. 2002. Genetic diversity between Botrytis cinerea isolates from unstored and cold stored kiwi fruit. J. Phytopathol. 150:629-635.

5. Boehm, E. W. A., Freeman, S., Shabi, E., and Michailides, T. J. 2003. Microsatellite primers indicate the presence of asexual populations of Venturia inaequalis in coastal Israeli apple orchards. Phytoparasitica 31:236-251.

6. Burt, A., Carter, D. A., Koenig, G. L., White, T. J., and Taylor, J. W. 1996. Molecular markers reveal sympatric sex in the human pathogen Coccidioides immitis. Proc. Natl. Acad. Sci. USA 93:770-773.

7. Buttner, P., Koch, F., Voigt, K., Quidde, T., Risch, S., Blaich, R., Bruckner, B., and Tudzynski, P. 1994. Variation in ploidy among isolates of Botrytis cinerea: Implications for genetic and molecular analyses. Curr. Genet. 25:445-450.

8. Delcán, J., Moyano, C., Raposo, R., and Melgarejo, P. 2002. Storage of Botrytis cinerea using different methods. J. Plant Pathol. 84:3-9.

9. Diolez, A., Marches, F., Fortini, D., and Brygoo, Y. 1995. Boty, a long-terminal-repeat retroelement in the phytopathogenic fungus Botrytis cinerea. Appl. Environ. Microbiol. 61:103-108.

10. Fournier, E., Giraud, T., Loiseau, A., Vautrin, D., Estoup, A., Solignac, M., Cornuet, J. M., and Byrgoo, Y. 2002. Characterization of nice polymorphic microsatellite loci in the fungus Botrytis cinerea (Ascomycota). Mol. Ecol. Notes 2:253-255.

11. Fournier, E., Levis, C., Fortini, D., Leroux, P., 
Giraud, T., and Brygoo, Y. 2003. Characterization of Bc-hch, the Botrytis cinerea homolog of the Neurospora crassa het-c vegetative incompatibility locus, and its use as a population marker. Mycologia 95:251-261.

12. Giraud, T., Fortini, D., Levis, C., Lamarque, C., Leroux, P., LoBuglio, K., and Brygoo, Y. 1999. Two sibling species of the Botrytis cinerea complex, transposa and vacuma, are found in sympatry on numerous host plants. Phytopathology 89:967-973.

13. Giraud, T., Fortini, D., Levis, C., Leroux, P., and Brygoo, Y. 1997. RFLP markers show genetic recombination in Botryotinia fuckeliana (Botrytis cinerea) and transposable elements reveal two sympatric species. Mol. Biol. Evol. 14:1177-1185.

14. Hantula, J., Dusabenyagasani, M., and Hamelin, R. 1996. Random amplified microsatellites (RAMS): A novel method for characterizing genetic variation with fungi. Eur. J. Pathol. 26:159-166.

15. Jarvis, W. R. 1980. Epidemiology. Pages 219250 in: The Biology of Botrytis. J. R. ColeySmith, K. Verhoeff, and W. R. Jarvis, eds. Academic Press, London.

16. Leroux, P., Chapeland, F., Desbrosses, D., and Gredt, M. 1999. Pattern of cross-resistance to fungicides in Botryotinia fuckeliana (Botrytis cinerea) isolates from French vineyards. Crop Prot. 18:687-697.

17. Leroux, P., Fritz, R., Debieu, D., Albertini, C., Lanen, C., Bach, J., Gredt, M., and Chapeland, F. 2002. Mechanisms of resistance to fungicides in field strains of Botrytis cinerea. Pest Manag. Sci. 58:876-888.

18. Levis, C., Fortini, D., and Brygoo, Y. 1997. Flipper, a mobile Fot1-like transposable ele- ment in Botrytis cinerea. Mol. Gen. Genet. 254:674-680.

19. Lorbeer, J. W. 1980. Variation in Botrytis and Botryotinia. Pages 19-40 in: The Biology of Botrytis. J. R. Coley-Smith, K. Verhoeff, and W. R. Jarvis, eds. Academic Press, London.

20. Ma, Z., Boehm, E. W. A., Luo, Y., and Michailides, T. J. 2001. Population structure of Botryosphaeria dothidea from pistachio and other hosts in California. Phytopathology 91:665-672.

21. Martinez, F., Blancard, D., Lecomte, P., and Levis, C. 2003. Phenotypic differences between vacuma and transposa subpopulation of Botrytis cinerea. Eur. J. Plant Pathol. 109:479488.

22. McDermott, J. M., and McDonald, B. A. 1993. Gene flow in plant pathosystems. Annu. Rev. Phytopathol. 31:353-373

23. McDonald, B. A. 1997. The population genetics of fungi: Tools and techniques. Phytopathology 87:448-453.

24. McDonald, B. A and Linde, C. 2002. Pathogen population genetics, evolutionary potential, and durable resistance. Annu. Rev. Phytopathol. 40:349-379.

25. McDonald, J. F. 1993. Evolution and consequences of transposable elements. Curr. Opinion Genet. Development 3:855-864.

26. Michailides, T. J., and Elmer, P. A. G. 2000. Botrytis gray mold of kiwifruit caused by $\mathrm{Bo}$ trytis cinerea in the United States and New Zealand. Plant Dis. 84:208-223.

27. Muňoz, G., Hinrichsen, P., Brygoo, Y., and Griaud, T. 2002. Genetic characterization of Botrytis cinerea populations in Chile. Mycol. Res. 106:594-601.

28. Taylor, J. W., Geiser, D. M., Burt, A., and
Koufopanou, V. 1999. The evolutionary biology and population genetics underlying fungal strain typing. Clin. Microbiol. Rev. 12:126146.

29. Thompson, J. R., and Latorre, B. A. 1999 Characterization of Botrytis cinerea from table grapes in Chile using RAPD-PCR. Plant Dis. 83:1090-1094.

30. Vallejo, I., Carbu, M., Munoz, F., Rebordinos, L., and Cantoral, J. M. 2002. Inheritance of chromosome-length polymorphisms in the phytopathogenic ascomycete Botryotinia fuckeliana (anam. Botrytis cinerea). Mycol. Res. 106:1075-1085.

31. Van Der Vlugt-Bergmans, C. J. B., Brandwagt, B. F., Van't Klooster, J. W., Wagemakers, C. A M., and Van Kan, J. A. L. 1993. Genetic variation and segregation of DNA polymorphism in Botrytis cinerea. Mycol. Res. 97:1193-1200.

32. Weising, K., Atkinson, R. G., and Gardner, R. C. 1995. Genomic fingerprinting by microsatelliteprimed PCR: A critical evaluation. PCR Method Appl. 4:249-255.

33. White, T. J., Bruns, T., Lee, S., and Taylor, T. 1990. Amplification and direct sequencing of fungal ribosomal RNA genes for phylogenetics. Pages 315-322 in: PCR Protocols: A Guide to Methods and Applications. Academic Press, San Diego, CA.

34. Zietkiewicz, E., Rafalski, A., and Labunda, D. 1994. Genome fingerprinting by simple sequence repeat (SSR) anchored polymerase chain reaction amplification. Genomics 20:178-183.

35. Ziogas, B. N., Markoglou, A. N., and Malandrakis, A. A. 2003. Studies on the inherent resistance risk to fenhexamid in Botrytis cinerea. Eur. J. Plant Pathol. 109:311-317. 